\title{
Plasma Erythropoietin in Newborn Lambs
}

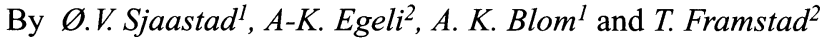 \\ ${ }^{1}$ Department of Biochemistry, Physiolology and Nutrition, and ${ }^{2}$ Department of Reproduction and Forensic \\ Medicine, The Norwegian School of Veterinary Science, Oslo, Norway.
}

\begin{abstract}
Sjaastad ØV, Egeli A-K, Blom AK, Framstad T: Plasma erythropoietin in newborn lambs. Acta vet. scand. 2000, 41, 381-385. - In the present study early postnatal changes in erythropoietin (Epo) level and hemoglobin concentration in 8 lambs were examined. Plasma Epo was estimated by a monoclonal enzyme-immunoassay ( ELISA), developed for human Epo. In all the lambs, except one, Epo was low, or undetectable, immediately after birth. Within 6-12 h after birth, a marked increase in plasma Epo was found in 4 of the lambs. Within 3-7 days after birth, Epo was back to low levels. In the lamb with high Epo levels at birth, drastic decreases were observed during the next $6 \mathrm{~h}$. There was no obvious correlation between the hemoglobin concentrations and the changes in plasma Epo.
\end{abstract}

neonatal changes.

\section{Introduction}

Erythropoiesis is regulated through a feedback loop, involving erythropoietin (Epo), a peptide hormone mainly produced in the kidneys in adults. Hypoxia, either caused by anaemia, hypobaria or ischemia, is generally supposed to be the fundamental stimulus to trigger Epo production in the kidneys (e. g. Jelkmann 1992). Whether this is so in newborns is disputable. In accordance with the hypoxia theory, Halvorsen \& Finne (1968) reported that a change from placenta to the lungs as the respiratory organ is associated with a reduction in erythropoietic activity in man. This is not supported by the findings of low erythropoietic activity in plasma of premature babies (Brown et al. 1984). Hågå et al. (1983) proposed that other factors than hypoxia, such as weight gain, might be of importance in the control of Epo production in early life.

In contrast to the findings of Halvorsen \& Finne (1968) in man, an increase in erythropoietic activity was found in piglets during their early postnatal period (Sjaastad et al. 1992). In lambs, Zanjani et al. (1977), using bioassay, obtained results indicating an increase in erytropoietic activity from late fetal life until a few $\mathrm{h}$ after birth. In sheep, Wintour et al. (1990) found that plasma Epo was lower during late fetal life than during the first weeks after birth. In their studies blood samples were, however, taken only twice a week. Since very rapid changes have been found to take place in the early postnatal period of pigs (Sjaastad et al. 1992), we consider it of interest to examine more closely the changes of plasmaEpo during the first days of life also in lambs.

\section{Materials and methods}

Eight lambs from four ewes of the Dala and Ryggja breeds were examined. The parturition took place indoors in April. The ewes were kept in separate stalls during labour and 24 hours onwards. Blood samples of the lambs were taken before the first sucking and at predetermined points of time thereafter. Plasma Epo was estimated by monoclonal enzyme-immunoassay 


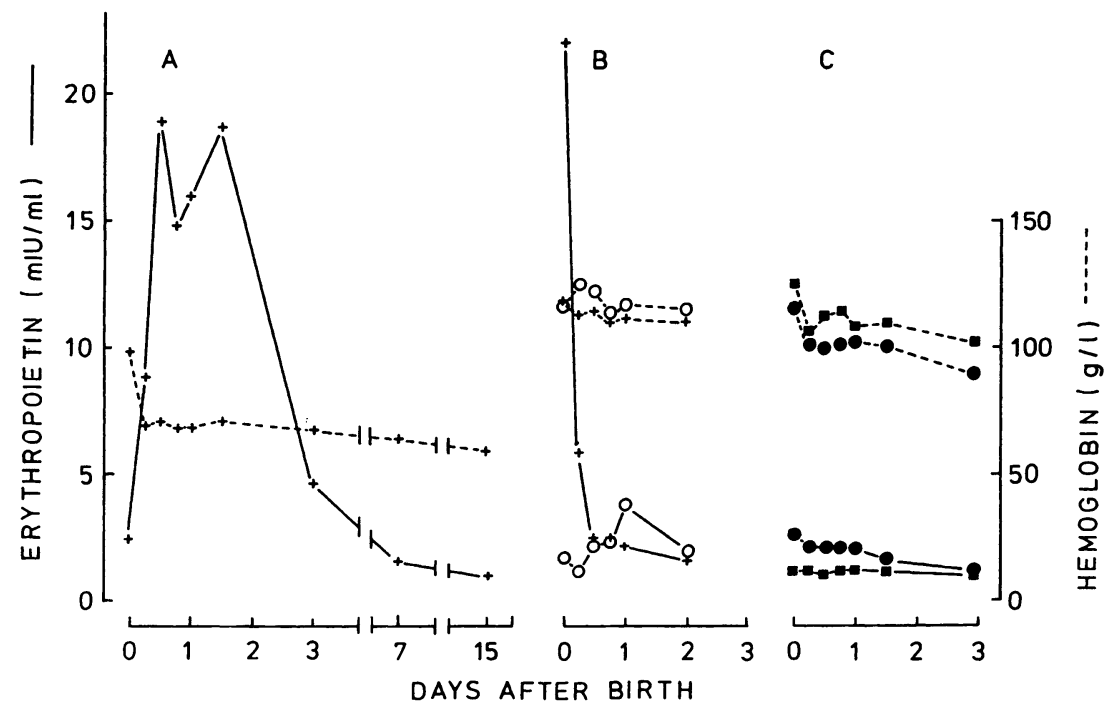

Figure 1. Early postnatal Epo activity (solid lines) in three lambs from the same mother. The hemoglobin values (broken lines) are means and SD.

(ELISA), using human Epo antibodies (EpoElisa test, Medac, Hamburg, Germany). Since ovine Epo was not available, the degree of crossreaction between this antigen and the antibodies used could not be tested, and thus only relative values for Epo are given.

In 4 of the lambs, plasma Epo was not systematically examined in samples collected after the first 3 days of life, since the samples examined were all below the detection limit of the method.

The coefficient of interassay variation of the method was about 10 per cent. Hemoglobin concentration was estimated by Technicon $\mathrm{H}^{*}$, Bayer, USA.

\section{Results}

In 4 of the lambs, low values of Epo were found in all blood samples collected the first 3 days of life. In these lambs, plasma Epo in samples collected at a later stage were below the detection limit of the method. In all the lambs, except one, plasma Epo was low, or undetectable, at birth (Figs. 1\&2). In one lamb (Fig 1 B), the Epo level was intermediate at birth, whereafter it fell abruptly during the next $6 \mathrm{~h}$. In 4 of the other lambs, there was a marked increase in plasma Epo during the first day of life. This increase was demonstrable as early as $6 \mathrm{~h}$ after birth in one lamb (Fig. $1 \mathrm{~A}$ ), in the remaining 3 it was present at $12 \mathrm{~h}$ (Fig. 2). The magnitude of the increase, and the level of the maximal Epo values, varied largely between the lambs, also within twins or triplets (Figs. 1B \&2). Nevertheless, the peak Epo values of 2 of the 3 lambs from the same mother (Fig. 2), far exceeded the corresponding Epo values in any of the other lambs. Within 3-7 days after birth, plasma Epo was down to low values.

The hemoglobin concentration at birth varied between 95 and $130 \mathrm{~g} / \mathrm{l}$. In all the lambs hemoglobin decreased during the first days of life. 


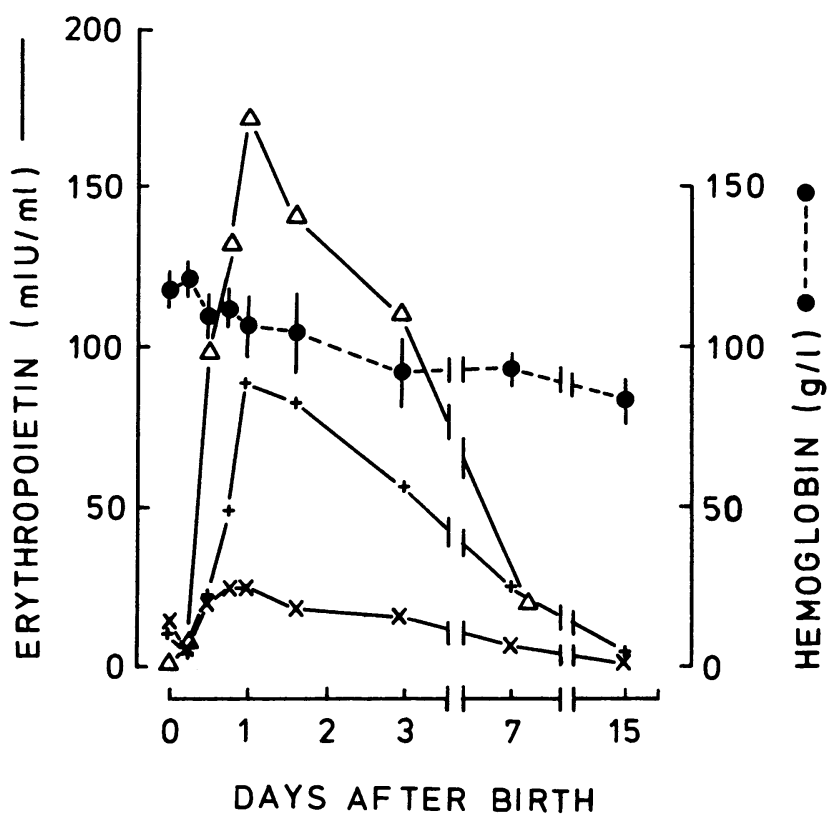

Figure 2. Early postnatal Epo activity (solid lines) and hemoglobin (broken lines)in one single lamb and two pairs of twin lambs. Note that the scale for Epo is different from the one used in Figure 1.

This decrease was in some of the lambs as large as $25 \%$. There was no obvious correlation between hemoglobin concentration and plasma Epo at birth.

\section{Discussion}

Since ovine Epo is not available, only relative values of Epo concentrations can be given in sheep (see Materials and methods). Studies of DNA-sequences have, however, indicated that Epo is well preserved during evolution. Thus, interspecies immunoreactivity of Epo is believed to be large (Jelkmann 1992). Nevertheless, it has been argued that antibodies against human Epo, as used in the present study, are not suitable for analyses in other species, since linearity is not obtained upon plasma dilution (Jelkmann 1992). In the present study, excellent linearity upon dilution of lamb plasma was ob- tained. The heterologous method used should thus be adequate.

The partial oxygen pressure in the placental vessels is low compared to the corresponding pressure in the lungs after birth. The various mammalian species use different strategies to compensate for the unfavourable situation for oxygen transfer in the placenta. Nevertheless, during the last part of pregnancy, when fetal growth is rapid, the fetuses of examined domestic animals exhibit a varying degree of hypoxia (Comline \& Silver 1974, Wintour et al. 1990). Since hypoxia is the principal physiological stimulus for erythropoietin production in humans and experimental animals (e.g. Jelkmann 1992), erythropoietin activity should, a priori, be expected to increase during fetal life. And such an increase in erythropoietic activity during fetal life has indeed been demonstrated in 
man (Halvorsen \& Finne 1968, Thomas et al. 1983). In pigs, however, a species in which oxygen transfer is particularly problematic and fetal growth rapid, erythropoietin is below detection limits in blood samples collected immediately after birth (Sjaastad et al. 1992). The problematic transfer of oxygen from the mother to the fetal pig is due to a combination of low partial pressures of oxygen in the placenta, low fetal hemoglobin, and lack of counter-current flow in the placental vessels.

In fetal lambs, Zanjani et al. (1977), using bioassay, were unable to detect erythropoietic activity in plasma at any stage of pregnancy, whereas Lim et al. (1994) demonstrated the presence of Epo mRNA in the liver and kidney at all stages of pregnancy. Lim et al. (1994) also demonstrated the presence of immuno-reactive Epo in plasma at 60-65 days of pregnancy, the only point of time examined for such activity. In the present study, Epo was low immediately after birth in all lambs, except one. The very low levels of Epo in plasma at birth in most lambs is probably a reflection of similar low levels in the last part of pregnancy. Such low levels are somewhat surprising, because growth probably is rapid and erythropoiesis active at this stage of fetal life, and as the lambs most probably suffer from hypoxic hypoxia, and since Lim et al. (1994) found high levels of Epo mRNA at 140 days of pregnancy. In this context it is worthwhile to mention that in the rat, the Epo response to hypoxic hypoxia is much less in newborns than in adults (Caro et al. 1982). A combination of rapid growth, active erythropoiesis, hypoxic hypoxia and nearly undetectable Epo activity at birth has also been reported in pigs (Sjaastad et al. 1992). The hypoxic stimulation might be even stronger in fetal pigs than fetal lambs, since newborn piglets do not suffer only from hypoxic hypoxia, but also from anemic hypoxia. The observations in newborn pigs and lambs suggest that regulation of eryth- ropoiesis during late fetal life differs from the regulation in adults. Such an assumption is supported by the observation of Hågå et al. (1983), who found no correlation between hemoglobin and erythropoiesis stimulating activity in premature babies. It is possible, however, that changes in plasma levels of Epo depends on the duration of a hypoxic situation. When leukemic patients are given cytostatic treatment, the abrupt initial increase in Epo was followed by a rapid decrease, despite the fact that the reduction in oxygen transport capacity, induced by the treatment, persisted (Jelkmann \& Wiedemann 1990).

The fact that the increases in plasma Epo after birth appeared within a few $h$, makes it unlikely that they were due to the post partum decrease in hemoglobin. More probably the Epo changes were due to acute stress during the delivery process. The fetuses may have been subjected to acute hypoxia and both glucocorticoids and prostaglandins, hormones which change in concentration during the parturition prosess, have been shown to influence Epo production (Peschle et al. 1971, Paulo et al. 1973, Gross et al. 1976, Moritz et al. 1997). Acute hypoxia increases kidney mRNA within 6-12 h (Eckardt et al. 1990). The time course, as well as the inconsistency of the early postnatal Epo changes, might point to hypoxia as the most likely candidate for being the stimulator of increased Epo synthesis. Further studies are, however, required to elucidate the mechanisms behind the perinatal changes in plasma.

The rapid changes in Epo levels in the early neonatal period observed in the present study is an interesting phenomenon. Caution should, nevertheless, be exercised in the interpretation of its physiological significance, because of the inconsistency of the findings. 


\section{References}

Brown MS, Garcia JF, Phibbs RH, Dallman PR: Decreased response of immunoreactive erythropoietin to "available oxygen" in anemia of prematurity. J. Pediatr. 1984, 105, 793-798.

Caro J, Erslev AJ, Silver R, Miller O,Birgegard G: Erythropoietin production in response to anemia or hypoxia in the newborn rat. Blood. 1982, 60, 984-988.

Comline RS, Silver M: Placental transfer of blood gases. Br Med Bull 1975, Jan; 31(1), 25-31

Eckardt KU, Dittmer J, Neumann R, Bauer Ch, Kurtz $A$ : Decline of erythropoietin formation at continuous hypoxia is not due to feedback inhibition. Am. J. Physiol. 258 (Renal Fluid Electrolyte Physiol. 27). 1990 F 1432- F 1437.

Halvorsen S, Finne RH: Erythropoietin production in the human fetus and newborn. Ann. N.Y. Acad. Sci. 1968, 149, 576-577.

Hågå P, Meberg A, Halvorsen S: Plasma erythropoietin concentrations during the early anemia of prematurity. Acta. Pediat. Scand. 1983, 72, 827831.

Gross DM, Brookins J, Fink GD, Fisher JW: Effects of prostaglandin $\mathrm{A}_{2}, \mathrm{E}_{2}$ and $\mathrm{F}_{2 \mathrm{a}}$ on erythropoietin production. J. Pharmacol. Exp. Ther. 1976, 198, 489-496.

Jelkmann W, Wiedemann G: Serum erythropoietin level: relationships to blood hemoglobin concentration and erythropoietic activity of the bone marrow. Klin. Wochenschr. 1990, 68, 403-407.

Jelkmann $W$ : Erythropoietin: structure, control of production and function. Physiol. Rev. 1992, 72, 449- 489.

Lim GB, Darby I, Jeyaseelan K, Wintour EM: Ontogeny and regulation of erythropoietin gene expression in the ovine fetus. Clin. Invest. 1994, 72, B 16.

Moritz KM, Lim GB, Wintour EM: Developmental regulation of erythropoietin and erythropoiesis. Am. J. Physiol. 1997, 273, 1829-1844.

Paulo LG, Wilkerson RD, Roh BL, George WJ, Fisher $J W:$ The effects of prostaglandin $\mathrm{E}_{2}$ on erythro- poietin production. Proc. Soc. Exp. Biol. Med. 1973, 142, 771-775.

Peschle C, Sasso GF, Mastroberandino G, Condorelli $M$ : The mechanism of endocrine influences on erythropoiesis. J. Lab. Clin. Med. 1971, 78, 2029.

Sjaastad $\varnothing V$, Framstad $T$, Blom $A K$ : Neonatal changes in plasma erythropoietin in fast growing pigs. Acta. Vet. Scand. 1992, 37, 133-138.

Thomas RM, Canning CE, Cotes PM, Linch DC, Rodeck $C H$, Rossiter $C E$, Huehns ER: Erythropoietin and cord blood haemoglobin in the regulation of human fetal erythopoiesis. Brit. J. Obstr. Gynaecol. 1983, 90, 795-800.

Wintour EM,Clemons $G$, Butkus A,Horvath A, Moritz $K$ Towstoless $M K$ : Immunoreactive erythropoietin concentration and haemoglobin type in the perinatal period in sheep of various haemoglobin genotypes. J. Dev. Physiol.. 1990, 14, 259-265

Zanjani ED, Poster J, Mann LI, Wasserman LR: Regulation of erythropoiesis in the fetus. Kidney Hormones, Vol II. Erythropoietin. Fisher JW. ed. 1977 Academic Press, 463-493.

\section{Sammendrag \\ Erytropoietin i plasma hos nyfødte lam.}

Erytropoietin (Epo) i plasma og blodets hemoglobinkonsentrasjon ble hos 8 lam undersøkt de første dagene etter fødsel. PlasmaEpo ble målt med en monoklonal enzym-immunoassay (Elisa), utviklet for humant Epo. Umiddelbart etter fødsel var Eponivåne i plasma lave, eller ikke målbare, hos alle lammene, untatt ett. I løpet av 6-12 timer etter fødsel økte Epo-nivået betydelig hos 4 av de 7 resterende lammene. Etter 3-7 dager var plasmaEpo igjen nede på et lavt nivå. Hos lammet med høyt Epo ved fødsel, falt nivået drastisk de 6 første timene etter fødselen. Det var ingen tydelig sammenheng mellom hemoglobinkonsentrasjonen og forandringene i plasmaEpo.

(Received April 20, 2000; accepted August 20, 2000).

Reprints may be obtained from: Ø.V. Sjaastad, Physiology and Nutrition, The Norwegian School of Veterinary Science, Postboks 8146, Oslo-Dep., N-0033 Oslo, Norway. tel: +47 229645 82, fax: +47 22600985. 